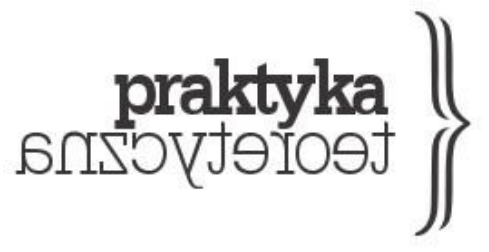

Praktyka Teoretyczna

Numer 4(18)/2015

ISSN 2081-8130

DOI: $10.14746 /$ prt.2015.4.7

www.praktykateoretyczna.pl

\title{
PRZEDMOWA TŁUMACZA
}

\author{
JĘDRZEJ BRZEZIŃSKI
}

Napisany w roku 1915 przez dwudziestotrzyletniego Waltera Benjamina esej „Życie studentów" można uznać za podsumowanie jego praktyczno-teoretycznej działalności z lat poprzednich, w dużej mierze koncentrującej się właśnie na kwestii reformy uniwersytetu, czy raczej, by użyć sformułowania autora, jego odnowy. Studiując we Freiburgu i Berlinie Benjamin angażował się w działalność lewicujących organizacji studenckich, inspirowanych choćby charyzmatyczną postacią Gustava Wynekena (z którego wpływem łączyć można heglowskie i nietzscheańskie inspiracje młodego Benjamina), tam jednak pogłębiał się również jego krytycyzm wobec zachowawczości tych stowarzyszeń i mieszczańskich podziałów, jakie odtwarzały. Potrzebę wspomnianej odnowy zauważa autor już w nieco patetycznym „Epilogu” (1912 rok), tekście opublikowanym anonimowo, przy okazji ukończenia przez siebie szkoły, w humorystycznym piśmie Bierzeitung der Kaiser-Friedrich-Schule. Skarży się w nim na „dręczące poczucie arbitralności i bezcelowości”, jakim razi szkolny program, na panującą w szkołach „wiecznie wpatrzoną w przeszłość obyczajowość” a także sztuczny i pochodny charakter wymyślanych przez nią zadań, nie mających nic wspólnego z istotnymi obowiązkami życia. Szkoła - stwierdzi młody krytyk - nie wyposaża w ideały, w których realizowałaby się jedność życiowych celów i naukowych środków. Uczy się tam pracy i posłuszeństwa, ale nie 
docieka wcale, co powinno stanowić ich właściwy przedmiot. W zażaleniu tym słychać oczywiście skargę prymusa-idealisty, rozczarowanego sztampą licealnego programu, te krytyczne obserwacje będą jednak, w coraz dojrzalszej formie, powracać w kolejnych tekstach, publikowanych zwłaszcza na łamach studenckiego czasopisma Der Anfang. Tekst przez nas prezentowany zbiera ich najważniejsze wątki. Tu także głównym przedmiotem krytyki jest generalne oddzielenie panujące pod rządami burżuazji, z jej urzędowym pragmatyzmem i wymogami profesjonalizacji, którego ofiarą padają wszystkie niemal sfery i formy życia. Ścisły podział naukowych kompetencji odpowiada wymogom zawodowstwa stawianym przez rynek, świadczy jednak również o zapomnieniu o źródłowej idei jedności wiedzy. Studia, zorganizowane według zasad, jakie narzuca im klasowy i państwowy interes rządzących, zamiast twórczo łączyć okres dzieciństwa z okresem dorosłości, okazują się je właśnie oddzielać. Wymogi uniwersyteckiego życia dopełniają asymilacji niezinstrumentalizowanej jeszcze, dziecięcej wyobraźni. Jak pisze w swej poświęconej Benjaminowi książce Michał Pospiszyl: „Zapinanie dziecka w mundur określonych ról, tożsamości i zachowań, było zarazem procesem wyjaławiania dziecięcej epistemologii zdolnej przy użyciu zniekształceń, błędów i przejęzyczeń odkrywać prawdę zabijaną przez encyklopedyczne sposoby myślenia" (Pospiszyl 2016, 172). Uwewnętrznienie logiki oddzielenia czyni tymczasem z benjaminowskich studentów prototypowych „ludzi jednowymiarowych”, niezdolnych do uchwycenia własnego życia w jego całości. Ta romantyczna wiara w całość i jedność (natury, wiedzy, jednostki), która razić tu może pewną emfazą, wyrażona zostanie w zamykającym okres pism wczesnych Benjamina spinozjańskim z ducha tekście „O języku ludzkim i języku w ogóle", zawierającym już zarys opartej na naturalnych podobieństwach i powinowactwach materialistycznej teologii. Jej wymiar mesjański zawsze wyłania się z tego, co najbardziej zwyczajne, popularne, codzienne, a co - jak stwierdzi Guy Debord - okazuje się „miarą wszystkiego". Krytyka oddzielenia i skupienie na życiu w jego wymiarze codziennym (gdzie splata się to, co prywatne i państwowe, religijne i sekularne, kapitalistyczne i anarchistyczne), to wątki ważne nie tylko dla całej późniejszej teorii krytycznej; powrócą one także w nastawionej na życie codzienne perspektywie współczesnego kulturoznawstwa, a także właśnie w tekstach sytuacjonistów. Widziany oczami Benjamina świat studencki, podobnie jak opisywany przez Guy Deborda spektakularny kapitalizm, ,,[z]e względu na swoje oddzielenie jest przestrzenią zwiedzionych spojrzeń i fałszywej świadomości. Zjednoczenie za pośrednictwem spektaklu nie jest zaś niczym innym jak oficjalnym językiem powszechnego oddzielenia" (Debord 2006, 34). 
Wyrażona w romantyczno-idealistycznym stylu krytyka wiedzy, która zatraciła swą jedność, i nauki, która zamiast wprowadzać poznającego w obiektywny byt idei stała się przymusem odtwarzania zadanych instrukcji, zawiera w formie zalążkowej to, co dokładniej uda się Benjaminowi wypowiedzieć w kategoriach marksistowskich. Krytykuje on niemiecką socjaldemokrację z jej powierzchownym przekonaniem, że wiedza zawsze pociąga za sobą władzę. Jak komentuje to Susan Buck-Morss:

[Socjaldemokracja] uwierzyła, że ta sama wiedza, która zapewnia dominację burżuazji nad
proletariatem pozwoli proletariatowi wyzwolić się spod jej władzy. Tak naprawdę jednak
wiedza pozbawiona związków z praktyka, niebędąca w stanie nauczyć proletariatu niczego
o jego sytuacji jako klasy, nie stanowiła żadnego zagrożenia dla jego ciemiężców.
Sprawdzało się to zwłaszcza w przypadku nauk humanistycznych (Buck-Morss 1989, 288).

Mieszczańska edukacja, będąca warunkiem wejścia na tak zwany rynek pracy, wytwarza jednocześnie swych funkcjonariuszy i proletariat, nigdy jednak nie dostarcza narzędzi pozwalających zakwestionować panujące między nimi stosunki. Prezentowany przez nas esej przenikliwie krytykuje alienujące funkcje szkolnictwa i trafnie przeczuwa możliwość konserwatywnego sojuszu wiedzy z władzą. Nie ogranicza się jednak do krytyki, albo raczej jego krytyka jest już krytyką ocalającą, mającą za zadanie odrywać i uwalniać potencjały, w jakie obfituje młodość z jej „radykalnie nowymi sposobami widzenia”. Benjamin czerpie inspiracje z pism romantyków, niepokornych bohaterów Goethego, Schillera i idei wychowania estetycznego (w którym piękno i swobodna gra okazują się środkami zaradczymi na nowoczesne oddzielenie), oraz wspomnianego Gustava Wynekena, z jego koncepcjami „kultury młodych” (Jugendkultur) i pedagogicznego erosa. Co ważne, krytyk wykracza jednocześnie poza te teorie jako zbytnio skupione na indywidualnym spełnieniu. Jego zdaniem połączona zainteresowaniami, marzeniami i wzajemną pomocą wspólnota jest niezbędną składową szczęśliwej młodości. Niemieckie szkoły tymczasem okazują się nie tylko urządzeniami oddzielenia, ale także popędowej represji, niezainteresowanymi twórczym pokierowaniem siłą niespętanego jeszcze przez monotonię rodzinnych obowiązków pragnienia, zdolnego stać się paliwem naukowych poszukiwań, impulsem eksperymentowania i tworzywem więzi. Zakłamana erotyczna konwencja przechwytuje pragnienie i zamyka je w obrębie zadań przyszłych ojców i matek, odtwarzających ten sam mityczny schemat dominacji. Theodor Adorno wyrazi podobną myśl, pisząc w notatkach do Dialektyki oświecenia:

Miłość dostaje stempel znaku fabrycznego, już z tej choćby racji, że realizuje się w szczelnie zorganizowanym systemie panowania. W Niemczech nawet promiskuityzm - jak kiedyś 
surowe obyczaje - jest dowodem posłuszeństwa wobec istniejącego stanu rzeczy, spełniany

z kim popadnie akt płciowy świadczy o zdyscyplinowanym podporządkowaniu się panującemu rozumowi (Adorno, Horkheimer 2010, 245).

Młody Benjamin przeczuwa już, że poddany regułom kapitalistycznego społeczeństwa uniwersytet zamienić się może, mówiąc językiem Foucaulta, w skupisko biopolitycznych urządzeń, których władza sięga najbardziej intymnych sfer i zawiaduje procesami upodmiotowienia. A jednak, co odkryje również Foucault, domena, w której przez naukę wytwarzana jest podmiotowość, to jednocześnie przestrzeń możliwego oporu. Dlatego studiowanie nazywa Benajmin także „koroną ascezy”. W tekście poświęconym Franzu Kafce w naukowym skupieniu opisywanego przez pisarza studenta Karla dostrzega ścieżkę wymknięcia się surowemu spojrzeniu ojca (por. Benjamin 2012, 154) Jak komentuje Pospiszyl:

Dlatego chociaż świat Kafki był tą samą epoka, o której Benjamin pisał w tekście o doświadczeniu i nędzy - epoką „najgłębszej wzajemnej alienacji ludzi, w czasach nieskończenie zapośredniczonych stosunków, które stały się ich jedynymi relacjami” a „od strony zapomnienia wieje przecież wicher", to zadaniem studentów było studiowanie rozumiane jako szarża przeciw tym wiatrom. [...] Studenci, jak wszyscy kafkowscy pomocnicy, wystarczająco dobrze znali bajkowy świat poprzedzający nadejście mitycznej przemocy, i to właśnie z jego perspektywy przyglądali się prawu (Pospiszyl, w przygotowaniu).

Obraz studenckiego życia, jaki wyłania się z tekstów Benjamina okazuje się więc podwójny. Z jednej strony życie to, wtłoczone w aparat zawodowych i urzędowych wymogów, nie jest nawet w stanie zadać pytania o swą pełną, witalną i wspólnotową formę. Z drugiej strony jednak - niczym w obrazie dialektycznym - odnaleźć może dostęp do nieskorumpowanych przez filisterski porządek potencjałów w twórczych możliwościach samej młodości i w jej „najbardziej zagrożonych, krytykowanych i wyśmiewanych wytworach czy ideach” (Benjamin 2015, 179). Jednocześnie romantyczna i materialistyczna, mesjańska i bezwzględnie krytyczna perspektywa Benjamina nie traci na aktualności, przeciwnie - dostarcza oglądu, który ożywczo wykracza poza poddane zasadzie oddzielenia dyscypliny. W epoce neoliberalizacji uniwersytetu, w której procesy separacji i urynkowienia wydają się stale nasilać, powrót do tej całościowej i - jak powie Benjamin - metafizycznej perspektywy, oraz nadziei, którą ujawnia, wydaje się wysiłkiem sensownym. 


\section{Wykaz literatury}

Adorno, Theodor i Max Horkheimer. 2010. Dialektyka oświecenia. Fragmenty filozoficzne. Tłum. M. Łukasiewicz. Warszawa: Wydawnictwo Krytyki Politycznej.

Buck-Morss, Susan. 1989. The Dialectics of Seeing. Walter Benjamin and the Arcades Project. Cambridge Mass.: MIT Press.

Benjamin, Walter. 2012. „Franz Kafka. Z okazji dziesiątej rocznicy jego śmierci”. Tłum. A. Lipszyc. W tegoż. Konstelacje. Wybór tekstów. Tłum. A. Lipszyc, A. Wołkowicz, Kraków: Wydawnictwo Uniwersytetu Jagiellońskiego: 225-262.

Benjamin, Walter. 2015. „Życie studentów”. Tłum. J. Brzeziński. Praktyka Teoretyçna 4(18): $\mathrm{XX}-\mathrm{XX}$.

Debord, Guy. 2006. Społeczeństwo spektaklu oraz Rozważania o społeczeństwie spektaklu. Tłum. M. Kwaterko. Warszawa: Państwowy Instytut Wydawniczy.

Pospiszyl, Michał. Zatraymać historię. Walter Benjamin i mniejszościony materialiżm. W przygotowaniu: książka ukażę się nakładem Wydawnictwa IBL PAN. 
Jędrzej K. Brzeziński - student w Instytucie Filozofii Uniwersytetu Warszawskiego, gdzie przygotowuje pracę magisterską poświęconą estetyce Jacques’a Ranciere’a. Tłumacz książki Gilles'a Deleuze'a Spinoza. Filozofia praktyczna.

\section{DANE ADRESOWE:}

Instytut Filozofii Uniwersytetu Warszawskiego

Krakowskie Przedmieście 3

00-097 Warszawa

EMAIL: jedrzejbrzezinski@gmail.com

CYTOWANIE: Brzeziński, Jędrzej. 2015. „Przedmowa tłumacza.” Praktyka Teoretycəna 4(18): 171-176.

DOI: $10.14746 /$ prt.2015.4.7

AUTHOR: Jędrzej Brzeziński,

TITLE: Translator's Preface 